\title{
The Worship of Swedish Saints in Poland after the Council of Trent
}

From the very beginning of Christianity saints have had an important place in liturgy. The earliest preserved liturgical books, such as lectionaries and sacramentaries, contain memorials of many saints who gave their lives for Christ or led lives that bore witness to the Gospel, therefore becoming a part of the Lord's paschal mystery. The memorials played an important role in the liturgical year, since Sundays were often given the name of the saint who had been honoured on that day. ${ }^{1}$ At first the cult had local character and concentrated around the grave of the saint. Many saints were venerated as patrons, protectors, mediators; villages and communities were entrusted to them. In the $4^{\text {th }}$ century the increase of importance of the cult of saints can be noticed. In many cases it became common practice. The development of the cult was influenced by many factors, such as migrations, creation of local, regional calendars and martyrologies, cult of relics and the popularisation of biographical literature, the most representative of which were the lives of saints. ${ }^{2}$ Although in the history of the Church there has been some abuse associated with this cult, it still is of great importance for the life of the Church, which was confirmed by the Second Vatican Council which stated that "by celebrating the passage

\footnotetext{
${ }^{1}$ Cf. J. W. Boguniowski, Rozwój historyczny ksiąg liturgii rzymskiej do Soboru Trydenckiego i ich recepcja w Polsce, Kraków 2001, p. 80.

${ }^{2}$ Cf. B. Nadolski, Liturgika, vol. 2, Poznań 1991, p. 160-162.
} 
of these saints from earth to heaven the Church proclaims the paschal mystery achieved in the saints who have suffered and been glorified with Christ; she proposes them to the faithful as examples drawing all to the Father through Christ, and through their merits she pleads for God's favor" (Constitution on the Sacred Liturgy Sacrosanctum Concilium, 104).

After the Council of Trent the cult of saints was given a new impulse in liturgy. As a result of liturgical books unification, the mentions of many saints venerated in local churches and orders were omitted. What is more, the liturgical texts, earlier based on unconfirmed testimonies, were compiled in a way that represented the historical truth. This task was given to Belgian Jesuits (The Bollandists) at the beginning of the 17 th century. ${ }^{3}$ Trying to preserve the cult of local saints in particular provinces and orders, appendices to the breviary and the missal were prepared. The custom of venerating Swedish saints in Poland, its origin and the particular saints who were put in the liturgical calendar is an interesting issue for analysis.

\section{Propium Poloniae and the Preservation of the Local Cult of Saints}

From the very beginning of the existence of the cult of saints, together with the celebrations from the general calendar, all places had particular days assigned for the celebration of their patron saints. These catalogues were supplemented by celebrations connected with the relics of saints enshrined in particular churches. These liturgical memorials

${ }^{3}$ The name comes from J. Bolland SI (1596-1665), a historian and hagiographer from Antwerp, who initiated publishing the Acta sanctorum. The main task of the Association was publishing critical editions of texts accompanied by scholarly commentaries. Currently the Bollandist Association is located in Brussels - cf. M. Daniluk, Bollandyści, Societas Bollandiana, [in:] Encyklopedia katolicka, vol. 2, Lublin 1976, col. 766-767. 
referred to particular places (locus) understood in a broad sense, as they also referred to a nation (natio), church province (provincia), or diocese (dioecesis). They could also concern the bishopric (civitas), another city in the diocese (oppidum) or parish (pagus, parochia). ${ }^{4}$ Common memorials constituted a separate group and adding them to local traditions was approved by the Holy See. They were compiled and issued as Missae propriae and Officia propria pro aliquibus locis. After the Council of Trent the number of missal and breviary forms changed. The greatest number of forms, both to venerate the mysteries of salvation and particular saints, could be found in liturgical books from the late $19^{\text {th }}$ and the early $20^{\text {th }}$ century. The relevance of some of them was questioned before the First Vatican Council (1869-1870). As a result of the reforms introduced by Benedict XIV (1740-1758) and Pius X (1903-1914) they were partly reduced, and in the edition of the Roman Missal from 1920 they got reduced significantly. ${ }^{5}$ The appendices containing liturgical texts of particular provinces and churches were called propia.

Propium Poloniae, an appendix to liturgical books, was prepared after the publication of the Roman Breviary in 1568 and the Roman Missal in 1570. These books contained the breviary offices and mass forms for the veneration of the saints who had been venerated in Poland for many centuries. Before the reform of the Council of Trent the memorials were put in missals and breviaries in use in particular dioceses. After the resolutions of the Council of Trent had been adopted in 1577 by the Episcopate of Poland, the liturgical books for Polish dioceses had to be issued. Revising and preparing new offices and mass forms required a lot of time. ${ }^{6}$ The preparation of the breviary offices became the responsibility of Stanisław Sokołowski (1537-1593), a priest, preacher and professor of the Academy of Cracow. The first

${ }^{4}$ Cf. A. Nowowiejski, Wykład Liturgji Kościoła Katolickiego, vol. 4, Płock 1916, p. 357-358.

${ }^{5}$ Cf. B. Nadolski, Liturgika, vol. 4, Poznań 1992, p. 66.

${ }^{6}$ Cf. W. Schenk, Służba Boża, [in:] Historia Kościoła w Polsce, ed. B. Kumor, Z. Obertyński, vol. 1, part 2, Poznań-Warszawa 1974, p. 363-364. 
offices composed by him referred to Saint Stanislaus and Saint Florian and were ready in 1589. He did not, however, live to see them printed, although the appendix was ready before his death. ${ }^{7}$ The first edition was printed in the Andrzej Piotrkowczyk printing house in 1596 in Cracow, under the title Officia propria dioecesium poloniae. ${ }^{8}$ The appendix to the Roman Missal was prepared by Kasper of Kleczów. Missae propriae Patronorum et festorum regni Poloniae were printed in the same printing house in $1605 .^{9}$

According to the first editions of Proprium Poloniae the memorials covered the following saints: Barbara (4 December), Eusebius (16 December ), Telesphorus (5 January), Bridget (1 February), Dorothy (6 February), Romuald (7 March), Casimir (4 March), transfer of St. Wenceslaus' relics (5 March), Cyril and Methodius (10 March), Francisca de Paula de Jesus (2 April), Adalbert (23 April), Peter Martyr (26 April), Sigismond (2 May), Florian (4 May), Stanislaus (8 May), saints Neri, Achilles, Domicilia and Pancras (12 May), Ephrem the Syrian (3 June), Antony of Padua (13 June), Margaret (13 July), Cristina (24 July), Hyacinth (16 July), Benigna (19 July), Sabina (29 July), Nicholas of Tolentino (10 September), Dalmatia (10 September), Januarius and Companions (19 September), Thyrsus (24 September), transfer of St.Stanislaus' relics (27 September), Wenceslaus (28 September), Placid and Companions, the Martyrs (5 October), Gereon and Companions,

${ }^{7}$ Cf. Sokołowski Stanisław, [in:] Encyklopedia kościelna, ed. M. Nowodworski, A. Zaremba, S. Biskupski, vol. 26, Warszawa-Płock-Włocławek 1903, p. 134-143; A. Nowowiejski, Wykład Liturgji Kościoła Katolickiego, op. cit., vol. 4, p. 381.

${ }^{8}$ Officia propria Patronorum Regni Poloniae, per R. Stanislavm Socolovivm, serenissimi olim Stephani Poloniae Regis Theologum, Canonicum Cracouiensem, ex mandato Synodi Petricouiensis conscripta, Auctore Illustrissimi Cardinalis Georgii Radzivili Episcopi Cracouiensis edita, Antverpiae 1676; cf. K. Estreicher, Bibliografia polska, vol. 23, Kraków 1909, p. 272.

9 Missae propriae Patronorum et festorum regni Poloniae, Ad normam Missalis Romani accomodatae, Cracoviae 1605; K. Estreicher, Bibliografia polska, vol. 22, Kraków 1907, p. 424-425; P. Sczaniecki, Msza po staremu się odprawia, Kraków 2009, p. 97-98. 
the Martyrs (10 October), Jadwiga the Widow (15 October), transfer of St. Adalbert's relics (20 October), Ursula and Companions (21 October), Benedict, John, Mathew Isaak and Krystyn, First Polish Martyrs (12 November), Elisabeth of Hungary (19 November), Presentation of the Blessed Virgin Mary (21 December). The list of saints evolved when new ones were added to the record, for instance when Stanislaus Kostka was canonised in $1726 .{ }^{10}$ Appendices containing offices and mass forms were also printed for monastic communities in Poland, such as propia of Polish Benedictines and Camaldoleses. ${ }^{11}$ In later editions common supplements for the Austrian Empire, Russia and Silesia were put. An example is an appendix to the Roman Missal from 1863 entitled Missae patronorum et festorum propriorum Regni Poloniae et Sueciae, item Russiae, Magni Ducatus Lithuaniae, et Ducatus Silesiae. ${ }^{12}$ Although during the First Vatican Council fr. Ricca from the Order of Minims postulated eliminating local celebrations from liturgical calendars, the project was rejected for fear of depleting the great diversity characteristic for the Church. ${ }^{13}$

\section{Polish-Swedish Union during the Vasa reign and the Proprium Sveciae}

The preservation of the cult of saints venerated in Sweden after the Council of Trent was partly influenced by the events connected with Sweden converting to the Augsburg Confession and the personal union during the Vasa reign between the Polish-Lithuanian

${ }^{10}$ Cf. Z. Wit, Patronał polski, [in:] Memoriale Domini. Ksiegga pamiątkowa dedykowana Księdzu Profesorowi Jerzemu Stefańskiemu w 70 rocznice urodzin, ed. M. Olczyk, W. Radecki, Gniezno 2010, p. 652-653.

${ }^{11}$ Cf. W. Pałęcki, Służba Boża kamedułów polskich. Tradycje życia liturgicznego w świetle potrydenckiej liturgii rzymskiej (1605-1963), Lublin 2012, p. 81-82.

${ }^{12}$ Ratisbonae 1963.

${ }^{13}$ Cf. A. Nowowiejski, Wykład Liturgji Kościoła Katolickiego, op. cit., vol. 4, p. 357. 
Commonwealth and the Kingdom of Sweden from 1592 to 1599. After the death of king John III of Sweden on 27 November 1952, his oldest son Sigismund III Vasa ( $\dagger 1632$ ) became heir to the throne of Sweden. Sigismund at that time was already the King of Poland. His uncle, Duke Charles of Södermanland $(\dagger 1611)$ had no children of his own, therefore, accepted the fact that his nephew took the throne. Having received permission of the Polish Parliament, Sigismund left the Commonwealth and went to Sweden to secure the Swedish crown. Since most of the Swedish population had converted to Lutheranism, during the synod summoned to Uppsala by Duke Charles in 1593 the Augsburg Confession was supported, the new Catholic liturgy was rejected, and an anti-Catholic confession of faith was drawn up, thus rejecting the missal introduced by King John III in 1576 which made the reformed liturgy similar to the Catholic one. ${ }^{14}$ King Sigismund III Vasa was a well educated, practising Catholic. Paolo Mucante ( $†$ 1617) - the secretary of the then legate in Poland Cardinal Enrico Gaetan $(\dagger 1599)$ - mentioned that the King prayed every day, said the rosary and the hours of the Virgin, every day listened to the read Holy Mass, later sung Holy Mass with a sermon, he kept Lent, participated in the Corpus Christi processions on foot, and on Good Fridays visited the graves of the Lord. ${ }^{15}$

King Sigismund III Vasa, in an attempt to keep the Swedish crown, on 19 February 1594 signed an agreement which guaranteed religious freedom to the Protestants. Only then was he crowned to be the King of Sweden by a Protestant archbishop Abraham Angermannus $(\dagger 1607)$. Unfortunately, soon after that he had to leave Sweden and gave regency to Charles of Södermanland and his senators. His uncle used the dislike that the lower nobility had towards the King who reneged on his earlier promises and opened Catholic schools and gave prominent posts to Catholics (e.g. the Mayor of Stockholm). Charles of Södermanland, pursuing his own political agenda, in 1595 openly

${ }^{14}$ Cf. Y. M. Werner, Schweden. I. Kirchengeschichte, [in:] Lexikon für Theologie und Kirche, Freiburg-Basel-Wien $2000^{3}$, vol. IX, col. 331.

${ }^{15}$ Cf. S. Ochmann-Staniszewska, Dynastia Wazów w Polsce, Warszawa 2007, p. 119. 
disobeyed the King by calling the Estates (Riksdag) to session, which turned into the anti-Polish confederation of the lower nobility. The attempt to end the conflict failed and on 24 July 1599 Sigismund was officially dethroned by the Riksdag. There was a proposal for the prince Władysław $(\dagger 1648)$ to take over the Swedish throne, however, on the condition that he would arrive in Sweden within six month in order to receive Protestant upbringing. Due to the lack of reaction on the Polish side, in 1600 the Estates made a decision to deprive the Vasas of the right to the Swedish crown, which they refused to accept. John II Casimir of Poland $(\dagger 1672)$ was forced to renounce his claim to the Swedish throne in Oliwa in 1660, although he was allowed to use the title of the King of Sweden till the end of his life. ${ }^{16}$

King Sigismund III Vasa never came to terms with the loss of the Swedish throne and never relinquished his desire to regain it. He asked for help both in the Commonwealth and abroad. It is possible that these personal experiences resulted in unifying the cult of the saints venerated in both countries before reformation. In response to reformation, religious fights, constant battles against the cult of saints and destroying their relics, King Sigismund III Vasa asked the Holy See for permission to include the Swedish saints in the Propium Poloniae. Having received the approval of the Sacred Congregation of Rites in 1616, dioceses could put these saints in their own calendars. ${ }^{17}$ The information found on the title page indicates that these offices come from an old Swedish breviary. ${ }^{18}$ In the $17^{\text {th }}$ century mass forms and breviaries were first printed as separate books. They were later included in the Propium Poloniae and were entitled either Officia or Missae propriae Poloniae et Sveciae. The author of the collection

${ }^{16}$ Cf. ibidem, p. 83-86.

${ }^{17}$ Cf. Z. Wit, Patronat polski, op. cit., p. 652.

${ }^{18}$ Cf. Officia propria SS. Patronorvm Regni Sueciae, Ex vetustis Breuiarijs eiusdem Regni deprompta: Ad instantiam Serenissimi Sigismundi III Svueciae \& Poloniae Regis, a Sac. Rituum Congregatione, auctoritate Apostolica, recognita \& approbata, atque omnibus tam in dicto Sueciae quam etiam Poloniae Regno habitantibus concessa, vt libere \& licite, translatis vel omissis aliis Officijs, Antverpiae 1678. 
of offices and forms is, however, unknown. In common editions they were ordered in accordance with the liturgical calendar and did not change over the centuries. ${ }^{19}$ In the $19^{\text {th }}$ century some dioceses resigned from mentioning the Swedish saints, an example of which has been Warmia since 1869. The last edition containing texts to venerate those saints is from 1901, and the next one, issued in 1914 by rev. J. Michalak (†1941), omits them completely. ${ }^{20}$

\section{Scandinavian Saints According to Proprium Sveciae}

The appendix of breviary offices and missal forms Proprium Sveciae remained unchanged over the centuries and contained memorials of the great saints of Scandinavia. In accordance with the monthly order the celebrations were to venerate the following: the preservation of the Kingdom with the intercession of St. Eric (6 January), Henry, the Bishop of Finland (19 January), transfer of St. Eric's relics (24 January), Ansgar (Oscar), the Bishop and Follower (4 February), Siegfried, the Bishop and Follower (25 February), Catherine of Sweden (23 March), Eric, the King and Martyr (18 May), the preservation of the Kingdom from the Holy Trinity form (21 May), Eskil, the Bishop and Martyr (12 June), memorial of all patron saints of the Kingdom of Sweden (the Sunday after the octave of St. Peter and St. Paul the Apostles), David (15 July), Botvid, the Martyr (28 July), Olaf, the King and Martyr (29 July), Helena, the Widow and Martyr (31 July), commemoration of Catherine of Sweden (2 August), Relics of the church in Uppsala

${ }^{19}$ Cf. A. Nowowiejski, Patronał polski i szwedzki, [in:] Encyklopedia kościelna, op. cit., vol. 18, p. 375-377; Z. Wit, Patronał polski, op. cit., p. 654.

${ }^{20}$ Cf. A. Nowowiejski, Wykład Liturgji Kościoła Katolickiego, op. cit., vol. 4, p. 381. 
(first Sunday after the feast of St. Matthew the Apostle), transfer of St. Eskil's relics (6 October) and Bridget (7 October). ${ }^{21}$

Propium Sveciae starts with a memorial of St. Eric Jedvardsson $(\dagger 1161)$, related to royal families of Denmark, Norway and Sweden. He was born about 1120 near Lake Melar. In 1155 he reigned the part of Sweden called Vestergötland. According to folk tales, he participated in the process of evangelisation of Finland, accompanying St. Henry. Legends say that he built many churches. He died a martyr in Old Uppsala, which at that time was the centre of pagan cults, while participating in the Holy Mass. This event was mentioned in the postconciliar Roman Martyrology. ${ }^{22}$ According to medieval calendars his liturgical feast was on 18 May. Another feast to venerate him was 24 January, when the transfer of his relics was celebrated. Most probably, the relics were placed in the Uppsala Cathedral in 1220, and his grave became a popular pilgrimage destination in the Middle Ages. His cult was propagated by the Brigittines. ${ }^{23}$ The third day when the intercession of St. Eric was expected was 6 January, when the Mass for the preservation of the Kingdom was celebrated. Up till the reformation times he was considered an exemplary ruler. ${ }^{24}$

${ }^{21}$ Officia propria SS. Patronorvm Regni Sueciae, Ex vetustis Breuiarijs eiusdem Regni deprompta: Ad instantiam Serenissimi Sigismundi III Svueciae \& Poloniae Regis, a Sac. Rituum Congregatione, auctoritate Apostolica, recognita \& approbata, atque omnibus tam in dicto Sueciae quam etiam Poloniae Regno habitantibus concessa, $v t$ libere \& licite, translatis vel omissis aliis Officijs, Antverpiae 1678, p. 4.

22 "Upsalae in Suecia, sancti Erici regis Noni, martyris, qui in regno suo ad populum sapienter regendum et mulierum iura tuenda incubuit et in Finniam sanctum Henricum episcopum misit, ut Christi fidem propagaret, tandem, dum Missae celebrationi adstabat, oppugnatus sub gladiis inimicorum cecidit" (Martyrologium Romanum Ex decreto sacrosancti oecumenici concilii Vaticani II Instauratum auctoritate Ioannis Pauli pp. II promulgatum, editio altera, Typis Vaticanis MMIV, p. 291).

${ }^{23}$ Cf. Księga imion i świętych, oprac. H. Fros, F. Sowa, vol. 2, Kraków 1997, col. 190.

${ }^{24}$ Cf. H. Lesman, J. Swastek, Eryk IX, [in:] Encylopedia katolicka, op. cit., vol. 4, col. 1102; T. Nyberg, Erich IX, [in:] Lexikon für Theologie und Kirche, op. cit., vol. 3, col. 766 . 
One of the great missionaries of Scandinavia was St. Henry ( $\dagger$ about 1157), who originally came from England. He came to Sweden about 1153 and together with St. Eric went to Finland. When Eric returned to Sweden, St. Henry stayed there to build the structures of the Church. However, soon after that, on 19 January about 1160, he died a martyr, killed by a peasant whom he had punished for murder. ${ }^{25}$ In the current Roman Martyrology his memorial is put on the 20 January, and the elogium states that he was murdered. ${ }^{26} \mathrm{He}$ was buried in Nousiajnen and between 1290 and 1300 his body was moved to Abo (Turku), where his relics were kept until 1720. They were taken by the Russians. The relics from Uppsala were removed during reformation times. His cult was widespread across Scandinavia, not only in Finland. ${ }^{27}$

After the Second Vatican Council in the reformed common calendar the memorial of St. Ansgar $(\dagger 865)$ was put on 3 February. In the Roman Martyrology it was pointed out that as the papal legate of Gregory IV (827-844) he was responsible for the process of evangelisation of northern Europe (Denmark and Sweden) and established the Holy Church of Christ there. ${ }^{28}$ St. Ansgar was born about 801 in north-western France. He was schooled in the Benedictine Abbey in Corvey, and later joined the Benedictine Order. When Harald Klak ( $\dagger$ about 852 ), the prince of Denmark, asked the emperor to be baptised,

${ }^{25}$ According to Roman Martyrology the right date is 1157 - cf. Martyrologium Romanum, op. cit., p. 755.

26 "In Finnia, sancti Henrici, episcopi et martyris, qui, in Anglia natus, Upsaliensem Ecclesiam suscepit regendam omni studio in Finnos evangelizandos incumbens; crudeliter tandem ab homicida trucidatus est, quem iuxta ecclesiasticam disciplinam corrigere conatus erat" (Martyrologium Romanum, op. cit., p. 108).

${ }^{27}$ Cf. Księga imion i świętych, op. cit., vol. 3, col. 29; J. Swastek, Henryk z Uppsali, [in:] Encylopedia katolicka, op. cit., vol. 6, col. 690.

28 "Sancti Ansgarii, episcopi Hamburgensis ac postea insimul Bremensis in Saxonia, qui, primum monachus Corbeiensis, a Gregorio papa Quarto legatus deputatus est totius Septemtrionis, in Dania et Suecia gentium multitudini Evangelium nuntiavit et Christi Ecclesiam instituit, multas difficultates forti animo superans, donec Bremae laboribus defessus quievit” (Martyrologium Romanum, op. cit., p. 131). 
St. Ansgar accompanied him to proclaim the Gospel in those areas. After eighteen months he returned to the court of Louis the Pious $(\dagger 840)$, who sent him to Sweden in 830 to accomplish the same goals. Soon St. Ansgar became the bishop of Hamburg and a papal legate for northern countries. After the death of the bishop of Bremen, he was appointed his successor by the emperor, which met with disapproval of both the bishop of Cologne and the Pope. Between 852 and 853 he led to the conversion of the semi-legendary Swedish king named Olaf ( $\dagger$ after 854$)$ and attempted to organise Church structures there. He died on 2 or 3 February $865 .^{29}$

Born outside Scandinavia, St. Sigfrid ( $\dagger$ about 1045) was a Benedictine monk and bishop in Sweden. He originally came from England. He arrived in Norway invited by king Olof I Skötkonung († about 1021/1022), the first Christian ruler, where he evangelised the areas of today's Sweden in the early $11^{\text {th }}$ century. Around 1030 he came to Bremen. Not much is known about his life, but the centre of his cult became the city of Växjö in Sweden where his relics were enshrined. ${ }^{30}$ The first office to honour this saint is mentioned as early as 1206, and since 1474 he has been venerated as one of the main patron saints of Sweden. ${ }^{31}$ Initially his feast day in Proprium Sveciae was 25 February, later it was changed to 15 February. The latter is also the date under which the memorial of this saint is put in the current Roman Martyrology, with a comment on his zealous evangelisation works and information on the fact that he was the one who baptised king Olof. ${ }^{32}$

${ }^{29}$ Cf. Księga imion i świętych, op. cit., vol. 4, col. 461-462; P. Johanek, Ansgar, [in:] Lexikon für Theologie und Kirche, op. cit., vol. 1, col. 715-716; P. Kielar, Ansgar, [in:] Encylopedia katolicka, op. cit., vol. 1, col. 640-641.

${ }^{30}$ Cf. Księga imion i świętych, op. cit., vol. 6, col. 269.

${ }^{31}$ Cf. T. Nyberg, Siegfrid v. Schweden, [in:] Lexikon für Theologie und Kirche, op. cit., vol. 9, col. 569.

32 "Vexsiae in Suecia, sancti Sigfridi, episcopi, qui, ex Anglia oriundus, gentes huius regionis summa cum sedulitate evangelizavit et regem ipsum Olavum in Christo baptizavit" (Martyrologium Romanum, op. cit., p. 151). 
Catherine of Sweden $(\dagger 1381)$ was born around 1330. She was a daughter of St. Bridget of Sweden. She was schooled in the Cistercian Order in Riseberg. When she was about twelve or thirteen she married Lord Eggert van Kyren, a very religious young nobleman, whom she persuaded to take a vow of absolute chastity and both lived in a state of virginity. When St. Catherine was in Rome in 1350, her mother predicted the death of her husband. Consequently, Catherine decided to stay with her mother and together went on a pilgrimage to the Holy Land. After the death of her mother Catherine followed in her footsteps. She became the first abbess of the Monastery in Vadstena. While advocating for the canonisation of her mother, she came to Rome where Pope Gregory XI (1370-1378) initiated the process, and Pope Urban VI (1378-1389) approved it. Exhausted and sick, Catherine died in Vadstena in 1381. In 1484 the Holy See approved her cult, and the day for her veneration fell on 23 March. ${ }^{33}$ Additional commemoration to honour her was celebrated on 2 August. Currently her feast day is on 24 March. ${ }^{34}$ When the Monastery in Vadstena was closed in 1595, the relics of St. Catherine were buried in an unknown place. King Sigismund III Vasa was given St. Catherine's ring from the last abbess of this Monastery. ${ }^{35}$

Little is known about St. Eskil ( $†$ about 1080), the Bishop and Martyr. He was a monk of Anglo-Saxon origin who came to Sweden in order to do mission work. He was stoned about 1080 during a pagan riot. ${ }^{36}$ His feast day falls on 12 June, and the elogium mentions

${ }^{33}$ Cf. Księga imion i świętych, op. cit., vol. 3, col. 460-461.

34 "Vasteni in Suecia, sanctae Catharinae, virginis, quae, sanctae Birgittae filia, invita nuptum data virginitatem, coniuge consentiente, servavit et post eius obitum piam degit vitam; Romae et in Terra Sancta peregrina, matris reliquias in Sueciam transtulit et in monasterio Vastenensi asservavit, ubi habitum monialium ipsa induit“ (Martyrologium Romanum, op. cit., p. 204).

${ }^{35}$ Cf. J. Swastek, Katarzyna Szwedzka, [in:] Encylopedia katolicka, op. cit., vol. 8, col. 1002-1003.

${ }^{36}$ Cf. Księga imion iświętych, op. cit., vol. 2, col. 192; E. Hoffmann, Eskil v. Södermanland, [in:] Lexikon für Theologie und Kirche, op. cit., vol. 3, col. 883. 
both his martyr death and the great efforts he made in the name of Christ. ${ }^{37}$ Another feast celebrated in his honour was the day when his relics were transferred, which fell on 6 October.

St. David ( $\dagger$ about 1082), an abbot and bishop, also came from England. Before he came to Scandinavia about 1020 he was a Cluniac monk, St. Siegfried's companion and then a bishop in Västerås. He is venerated as the Apostle of Västmanland. Initially the place of his cult was the city of Munktorp where his relics were put four centuries after his death. They were transferred to the cathedral about 1463 , however, when Sweden was converted to Lutheranism, the sarcophagus was destroyed and his relics were buried in an unknown place in the cemetery. ${ }^{38}$ His memorial fell on 15 July, and, after the Second Vatican Council, the day was kept by the Martyrologium Romanum. The elogium mentions that he died in the monastery he had built. ${ }^{39}$

Among Scandinavian martyrs we can also find St. Botvid ( $\dagger$ about 1120). His cult was widespread across Scandinavia and his feast fell on 28 July. Unlike many other missionaries, he was native Swedish and came from Södertön. During a trade trip to England he learnt about Christianity and was converted to the Christian faith and baptised. According to legend, he came into contact with a pious priest who gave him shelter while he was abroad. Devoted to Christianisation, he was the apostle of Södermanland. St. Botvid was murdered by a slave whom he had baptised and given freedom. ${ }^{40}$ That is what the

37 "In Suecia, sancti Eskilli, episcopi et martyris, qui, genere anglus, a sancto Sigfrido magistro suo episcopus ordinatus, in Sudermannia provincia multis laboribus pro Christo apud paganos impense se tradidit, a quibus vero lapidatus est“ (Martyrologium Romanum, op. cit., p. 334).

${ }^{38}$ Cf. T. Nyberg, David, [in:] Lexikon für Theologie und Kirche, op. cit., vol. 3, col. 43.

39 "Arosiae in Suecia, sancti Davidis, episcopi, qui, anglus natione, Cluniacensis monachus factus ad convertendos Suecos ad Christum profectus est et in monasterio, quod condiderat, senex pie quievit“" (Martyrologium Romanum, op. cit., p. 391).

${ }^{40}$ Cf. Księga imion i świętych, op. cit., vol. 1, col. 499. 
elogium from Martyrologium Romanum states. ${ }^{41}$ St. Bridget of Sweden honoured him greatly.

Olaf II Haraldsson ( $\uparrow 1030)$, later known as St. Olaf, was the King of Norway. His feast fell on 29 July. When he was 12 he participated in a Viking expedition. He was a great country organiser who destroyed pagans and founded many churches. In 1028, however, he was forced to leave Norway, as he had incured the displeasure of some. Trying to regain the throne he was killed in the Battle of Stiklestad. His remains were enshrined in the Cathedral in Trondheim. ${ }^{42}$ His memorial fell on 29 July, and the day remained unchanged after the Second Vatican Council. ${ }^{43}$

St. Helena $(\dagger 1160)$ is another Swedish patron saint whose feast was celebrated on 31 July. He was a person of high birth and came from Skövde, Sweden. Having lost her husband as a very young woman, she dedicated herself to charity works. Around 1159 she undertook a pilgrimage to the Holy Land. Since he husband's family suspected she had killed him, she was murdered when she returned to Sweden. After her death, her intercession led to a number of miracles and the healing spring Elins Källa near the church became a pilgrimage destination. In 1164 her cult was approved by Pope Alexander III (1159-1181). Due to the popularity of the spring, the cult outlasted the period of reformation, and in 1759 her chapel was renovated. St. Helena was also venerated in Denmark. ${ }^{44}$ In

41 "In Suecia, sancti Botvidi, martyris, qui, suecus genere et in Anglia baptizatus, patriae evangelizationi se tradidit, donec a viro, quem ipse a servitute redemerat, occisus est" (Martyrologium Romanum, op. cit., p. 419).

${ }^{42}$ Cf. Księga imion i świętych, op. cit., vol. 4, col. 437-438.

43 "Nidarosiae in Norvegia, sancti Olavi, martyris, qui, rex gentis suae, quam fidem christianam in Anglia cognoverat, in regno suo idolatriam sedulo expugnans propagavit, sed postremo ab inimicis oppugnatus gladio occubuit" (Martyrologium Romanum, op. cit., p. 421).

${ }^{44}$ Cf. Księga imion i świętych, op. cit., vol. 3, col. 17; K. Kuźmiak, Helena Szwedzka, Elin z Skövde, [in:] Encylopedia katolicka, op. cit., vol. 6, col. 649. 
the short elogium in the Roman Martyrology her innocent death was emphasised. ${ }^{45}$

Saint Bridget of Sweden was a great mystic ( $\dagger 1373)$. She was born around 1302 near Uppsala, in a family related to the kings of Sweden. When she was fifteen she married Ulf Gudmarsson ( $\dagger$ 1344) and had eight children. She became known for her works of charity. She devoted herself to prayer and caring for the poor. She had a gift of visions, which she wrote down in Swedish. She and her husband went on pilgrimage to Santiago de Compostela. After their return, her husband joined the Cistercian Order in Alvastr, where he died shortly after. In 1346 she had a vision of founding a new order and she went to Rome in order to accomplish that goal. She waited for the return of the papacy to Rome from Avignon, which she had agitated for many years first with Pope Innocent VI (1352-1362), and then Pope Urban V (1362-1370). She went to the Holy Land with her daughter Catherine and her two sons. After her return to Rome, once again she tried to persuade Pope Gregory XI (1370-1378) to return to Rome. She precisely predicted the day of her own death, which happened in her own room during the Holy Mass. The Pope approved the Bridgettine rule and her work was continued by her daughter, Catherine. In 1623 her feast was inserted in the Roman Catholic calendar for celebration on 7 October. However, five years later it was moved to 8 October. After the reform of the calendar by the Second Vatican Council her feast is celebrated on 23 July. ${ }^{46}$ In her elogium there are mentions of her marriage, her piety, pious upbringing of her children, pilgrimages to the Holy Land and founding the Order of the Most Holy Saviour. ${ }^{47}$

45 "Schedviae in Suecia, sanctae Helenae, viduae, quae iniuste occisa martyr habetur" (Martyrologium Romanum, op. cit., p. 425).

${ }^{46}$ Cf. Księga imion i świętych, op. cit., vol. 1, col. 516-519; J. Kłoczowski, Brygida Szwedzka, Birgitta, [in:] Encylopedia katolicka, op. cit., vol. 2, col. 1115; T. Nyberg, Birgitta v. Schweden, [in:] Lexikon für Theologie und Kirche, op. cit., vol. 2, col. 478-479.

47 "Sanctae Birgittae, religiosae, quae, in Suecia nuptui Ulfoni legifero data, octo quos genuit filios piisime educavit et coniugem ipsum verbis et exemplis ad 
The celebration of the holy relics feast preserved in particular churches is an interesting issue. According to Proprium Sveciae, the celebration concerned the relics enshrined in the church in Uppsala and the feast itself took place in September, on the first Sunday after the feast of St. Matthew the Apostle (21 September). In the tradition of the Western Church the cult of relics played an important role and there were different celebrations connected with it: transfer (translatio), finding (inventio), elevation (elevatio, relevatio), relation (reductio, relatio), reposition (reservatio, repositio) and susception (susceptio reliquiarum seu corporum). The feasts to venerate relics, during which special breviary texts were said and the Holy Mass was celebrated in accordance with special forms, concerned the so-called major relics (insignes), not the minor ones (non insignes). The relics referred to as major were parts of the body such as the head, arm or hip of a saint. An important element of the celebration was the fact that the relic was physically present in the church where it took place. ${ }^{48}$ The cult of the Swedish saints points to the fact that the roots of Scandinavia are in the Christian faith. All patron saints of the Kingdom of Sweden were venerated together during one celebration which took place on Sunday after the octave of Peter and Paul the Apostles.

\section{Finishing Remarks}

The cult of the Swedish saints endured the difficult course of reformation owing to the annexation of Proprium Sveciae to Proprium

pietatem excitavit. Quo defuncto, multa per loca sacra peregrinata est et, de capite et membris Ecclesiae mystice reformandis scriptis relictis atque Ordinis Sanctissimi Salvatoris fundamentis actis, Romae migravit in caelum" (Martyrologium Romanum, op. cit., p. 406).

${ }^{48}$ Other major relics were the following parts of the body: heart, tongue, hand, brain, blood. If the major relic had broken and was repaired, it did not lose its value. Its authenticity, however, had to be confirmed by the bishop - cf. A. Nowowiejski, Wykład Liturgji Kościoła Katolickiego, op. cit., vol. 4, p. 386-389. 
Poloniae during the reign of the Vasa dynasty. Following the Propium Sveciae, eleven saints were venerated: eight men and three women. There was also one commemoration, two relics transfers, one common celebration of patron saints of the Kingdom of Sweden, one feast of relics and two celebrations for the preservation of the Kingdom. Altogether, in the oldest issues of propia they amounted to eighteen liturgical days a year. Among patron saints there were two kings, five bishops, one lay man and three women. Six of them died as martyrs. The relations between Scandinavia and England remain an interesting issue for analysis, as many Swedish patron saints came from England. Although till the end of the $19^{\text {th }}$ century the memorials of these saints were omitted in some Polish dioceses and they were also omitted in the Propium Poloniae published in 1914, two of them, St. Ansgar and St. Bridget of Sweden were inserted in the universal calendar after the Second Vatican Council.

Saints - both the ones from centuries ago and the ones from the near past - are exemplars of holiness and pleading prayer. They are no hindrance to the reconciliation of the Catholic Church with the reformed Churches. In patron saints the Church worships Christ whose glory shines in them. The splendour resulting from the Christological view of the cult of saints will be even brighter and clearer when it is built on a strong foundation of theological truth which makes it clear that Christ and only Christ is the only true mediator between God and man (cf. 1 Tim 2:5-6). The saints who introduced Scandinavia to Christianity can still be our intercessors and can become patron saints of the United Europe.

\section{Summary}

The Worship of Swedish Saints in Poland after the Council of Trent

After the Council of Trent memorials of many saints worshipped in local churches or religious communities were omitted as a result of the unification of the liturgical 
books. In order to maintain their cult in particular provinces or convents, appropriate appendices to the breviary and the missal were prepared. A new book of forms entitled Officium Divinum of saints worshipped in the territory of Poland prepared by Stanisław Sokołowski, canon of Cracow, was issued in Cracow in 1596. In 1605 an appendix containing missal forms developed by Kacper of Kleczowo was printed. As a result of the influence of the Reformation in Scandinavia, religious battles, fighting the cult of saints and the destruction of their relics, King Sigismund III Vasa asked the Holy See to grant the permission to include the Swedish saints in the Polish appendix to the missal devoted to the saints (Proprium Poloniae). Having received the approval issued by the Congregation of Rites in 1616, individual dioceses made decisions to include these saints in their own liturgical calendar. In the seventeenth century missal and breviary forms were first issued as separate editions, and then they were printed together with the Proprium Poloniae. This appendix, which had not changed over the centuries, contained the memorials of the great saints of Scandinavia, inter alia Eric, Henry, Ansgar, Siegfried, Eschil, Botvid, Olaf, Bridget and her daughter Catherine of Sweden. Towards the end of the nineteenth century, some dioceses no longer posted Swedish patrons (e.g. Warmia) and the last common issue of Polish and Swedish saints was released in 1901. Saints from the period of the beginning of Christianity in Scandinavia are still present intercessors and may become patrons of the United Europe.

\section{Keywords}

The cult of saints, the Council of Trent, Proprium Poloniae et Sveciae, Scandinavia

\section{Streszczenie}

\section{Kult świętych szwedzkich w Polsce po Soborze Trydenckim}

Po Soborze Trydenckim w wyniku unifikacji ksiąg liturgicznych pomięto w nich wspomnienia wielu świętych czczonych w kościołach lokalnych czy wspólnotach zakonnych. Chcąc zachować ich kult w poszczególnych prowincjach czy zakonach, przygotowywano odpowiednie dodatki do brewiarza i mszału. Nowa księga formularzy Officium Divinum świętych i błogosławionych czczonych na ziemiach Polski ukazała 
się w 1596 roku w Krakowie i przygotował ją kanonik krakowski Stanisław Sokołowski. W 1605 roku wydrukowano dodatek zawierający formularze mszalne opracowane przez Kaspera z Kleczowa. Na skutek wpływu reformacji w Skandynawii, walk religijnych, zwalczania kultu świętych oraz niszczenia ich relikwii, król Zygmunt III Waza zwrócił się do Stolicy Apostolskiej z prośbą o zezwolenie włączenia świętych szwedzkich do patronału polskiego. Po uzyskaniu zgody Kongregacji Obrzędów w 1616 roku poszczególne diecezje podejmowały decyzje o ich włączeniu do własnego kalendarza liturgicznego. W XVII w. formularze mszalne i brewiarzowe ukazywały się najpierw jako odrębne edycje, a później drukowano je razem z patronałem polskim. Dodatek ten, nie zmieniający się w ciągu wieków, zawierał wspomnienia wielkich świętych Skandynawii, m.in. Eryka, Henryka, Ansgara, Zygfryda, Eschila, Botwida, Olafa, Brygidy i jej córki Katarzyny Szwedzkiej. Pod koniec XIX wieku niektóre diecezje przestały zamieszczać patronów Szwecji (np. Warmia), a ostatnie wspólne wydanie patronału świętych polskich i szwedzkich ukazało się w 1901 roku. Święci stojący u początku chrześcijaństwa w Skandynawii są nadal aktualnymi orędownikami i mogą stać się patronami zjednoczonej Europy.

\section{Słowa kluczowe}

Kult świętych, Sobór Trydencki, Proprium Poloniae et Sveciae, Skandynawia 
